\title{
Cofradías y control eclesiástico en la Granada barroca
}

\author{
José Szmolka Clares *
}

Como es sabido las cofradías son asociaciones voluntarias y espontáneas de carácter laico que tienen un objetivo expresamente religioso relacionado formalmente con el culto a determinadas imágenes o advocaciones.

El carácter laico de sus miembros, la naturaleza multifuncional de sus fines, muchos de los cuales van más allá de su primordial fin religioso, y la espontaneidad de su origen han determinado desde un principio unas relaciones con la Iglesia oficial o institucional no siempre fluidas y cordiales. Incluso cuando la jerarquía eclesiástica fomentó las manifestaciones religiosas externas inherentes a este tipo de asociaciones y se apoyó en ellas, los excesos y comportamientos poco religiosos de las cofradías unido al excesivo celo, cuando no desconfianza, de algunos pastores, dieron lugar a numerosas reglamentaciones, sanciones y prohibiciones.

Desde la conquista y, sobre todo, tras las revueltas mudéjares de la Navidad de 1499 y los subsiguientes decretos de conversión, la Iglesia granadina demostró inequivocamente que representaba la religión de los vencedores $\mathrm{y}$, por tanto, la que imponía sus normas a toda la sociedad.

Por su parte, el granadino cristiano viejo convirtió la práctica religiosa en un símbolo de identidad lo que hizo que aquella tomara un doble significado que no se encuentra en los restantes dominios castellanos, pues se unió al suyo especifico otro de acusado sentido sociopolítico al proclamar la superioridad de la fe católica al tiempo que se expresaba pertenecer al grupo de los vencedores.

Esas circustancias hicieron de Granada una ciudad con una intensa vida religiosa que afectó por igual a todas las formas de expresión de-

* Universidad de Granada. 
vocionales y culturales y, por ende, a las prácticas penitenciales externas que desde mediados de siglo habían adquirido gran importancia.

\section{LAS PRIMITIVAS HERMANDADES GRANADINAS}

Diez eran las cofradias de penitencia que procesionaban por las calles granadinas en el último tercio del siglo xv ${ }^{1}$. Vera Cruz fundada en 1640 y que, como en la mayoría de las ciudades andaluzas, fue la pionera a la vez que marcaba una forma de realizar su estación penitencial que fue adoptada por casi todas las hermandades que le siguieron; salía el jueves santo desde el convento Casa Grande de San Francisco. Angustias y Transfixión de Nuestra Señora y Santas Úrsula y Susana, cuyos primitivos estatutos databan de 1545 y salía también el mismo día de una pequeña ermita extramuros que pronto, ante el incremento de la devoción, hubo de ser sustituida por un templo más capaz. Nuestra Señora de la Soledad y Entierro de Cristo vinculada al Carmen Calzado, fue erigida mediada la década de los cincuenta y salía del convento de Santa María de la Cabeza el viernes santo. Santo Crucifijo, Sangre de Jesucristo, Benditas Ánimas del Purgatorio y Santo Domingo que se transformó en hermandad de sangre en 1575 al pasar al cenobio dominicano de Santa Cruz la Real de donde salía el jueves santo. Sagrada Pasión de Cristo fundada algo después que la anterior en el monasterio de la Santísima Trinidad; salía la mañana del viernes santo. Santa Inspiración de Jesucristo y San Nicolás de Tolentino que procesionaba desde el convento de San Agustín la tarde del viernes santo. Santa Humildad y Paciencia de Jesucristo que se servía en el convento de Nuestra Señora de la Victoria de frailes mínimos de San Francisco de Paula y realizaba sus estaciones el miércoles. Sangre de Jesucristo, una hermandad vinculada a la orden de la Merced y que salía al día siguiente. Oración en el Huerto de los Olivos y Señor San Antón que residía en la ermita de este santo en las afueras de la ciudad; salía el miércoles santo y estaba unida a la Orden Tercera. Cruz de Santa Elena y Jesús Nazareno, la más moderna pues fue fundada por San Juan de la Cruz en 1587 durante su estancia en el convento descalzo de los Santos Mártires; salía el viernes santo de madrugada ${ }^{2}$.

\footnotetext{
Szmolka Clares, J., "La historia de la Semana Santa granadina desde sus orígenes al siglo XVIı", en Semana Santa en Granada. Sevilla, Ed. Gemisa, 1990, I, págs. 31 y ss.

a Szmolka Clares, J., "La devoción a Jesús Nazareno en Granada. La primitiva hermandad de las Cruces de Santa Helena y Jesús Nazareno", en Cristobal de Santa Catalina y las cofradias de Jesús Nazareno. Actas del Congreso Internacional. Córdoba 1991, págs. 443-451.
} 
Diez cofradías para una ciudad que apenas si rebasaba en esos años los cincuenta mil habitantes era una cantidad excesiva, máxime si se tiene en cuenta las numerosas y prósperas corporaciones de gloria existentes. Esta circunstancia influyó en su desarrollo e, incluso, en sus estaciones penitenciales y sería una de las razones que motivarían la intervención de los prelados.

En este sentido y dadas las especiales características de la religiosidad granadina, no es de extrañar que aqui se iniciaran

«experiencias pastorales, métodos de catequesis e, incluso, algunos aspectos organizativos que vieron su culminación en no pocos cánones aprobados en el Concilio de Trento. Es decir, algunos aspectos de la Iglesia de la Contrarreforma tuvieron un campo experimental en el Reino de Granada, donde, bajo el patronato real, sus autoridades religiosas intentaron organizar una Iglesia renovada en la que se tratasen de resolver los graves problemas de disciplina que tenían anquilosada la vida eclesiástica y que incidia negativamente en el sentimiento religioso de la población" ${ }^{3}$.

$Y$ esto fue lo que ocurrió en la capital del antiguo emirato nazarí en las postrimerías de la centuria en un momento en que se producía el tránsito de la Semana Santa penitencial a la barroca. El fenómeno, que obviamente no era exclusivo de estas tierras, respondía al ambiente y espíritu religioso surgido tras el Concilio.

Por un lado, los padres conciliares adoptaron una postura favorable a este tipo de manifestaciones culturales como se expresa en la sesión vigésimoquinta al ordenar a los obispos que

"enseñasen que por medio de las historias de los misterios de nuestra redención, representadas en pinturas $u$ otras reproducciones, se instruye y confirma el pueblo en el recuerdo y culto constante de los artículos de la fe, aparte de que de todas las sagradas imágenes se percibe grande fruto, no solo porque recuerdan al pueblo los beneficios y dones que le han sido concedidos por Cristo, sino también porque se ponen ante los ojos de los fieles los milagros que obra Dios por los santos y sus saludables ejemplos" ${ }^{4}$.

Pero, por otro lado, en su deseo de renovación disciplinar, la Iglesia pretendió controlar las prácticas litúrgicas unificándolas y despojándolas

3 Cortés Peña, A. L., "La religiosidad popular. La Inmaculada. El Sacromonte", en Reino de Granada. V Centenario. Granada, Ideal, 1992, II, pág. 115.

4 Denzinger, E., El Magisterio de la lglesia. Barcelona 1963, págs. 278-279. 
de muchas adherencias que poco tenían que ver con el verdadero sentido del culto.

De esta tarea se encargó en Granada el arzobispo don Pedro Guerrero, uno de los prelados españoles que más habían destacado en las sesiones conciliares. Como escribió Francisco Bermudez de Pedraza en su Historia eclesiástica de Granada, don Pedro

«pequeño de cuerpo pero gigante en la opinión, llegó a Granada (...) y halló su ganado mal tratado (...), y el buen Prelado puso las manos y el coraçón en curarle y apacentarle, y tratarle como suyo. Y para que la cura fuesse más acertada, dispuso un Concilio Provincial; junta de médicos espirituales que reconociese el humor de que pecava, y aplicase el remedio necesario" ${ }^{5}$.

\section{LAS CONSTITUCIONES SINODALES DE 1572}

Fruto de esas preocupaciones y del concilio provincial fueron las Constituciones Sinodales de $1572^{6}$. Aunque en ellas no se trata de una manera explícita y detallada la cuestión de las cofradías de penitencia como en otras similares - caso de las que promulgó para Sevilla don Rodrigo de Castro en 1586 y 1592 -, en algunos capítulos aparecen referencias suficientes sobre la postura de la jerarquía eclesiástica y el carácter específico de las hermandades.

En este sentido, en los títulos VII y XIII (De institutionibus et iure Patronatus y De religiosis et piis domibus) se recuerda la prohibición de erigir - permitir cofradías sin la aprobación o confirmación del ordinario, circunstancia esta última que demuestra la existencia de hermandades plenamente constituidas con anterioridad, incluso con reglas aprobadas.

«Ninguno hospitales, ermitas u otros lugares píos se instituyan o erijan en este nuestro Arzobispado sin licencia nuestra en escripto, ni se admitan cofradias en ninguna parroquia o monasterio dél, ni de las erigidas se use, hasta que tengan Constituciones y reglas por donde se gobiernen aprobadas por nos o nuestros provisores por escripto, so pena de dos mil maravedis a los cofrades, y la misma a los clérigos que las admitiesen

5 Bermúdez de Pedraza, F., Historia eclesiástica de Granada. Granada 1638, ed. facsimil 1989, fol. 236.

6 Constituciones sinodales del arzobispo de Granada en el Santo Sínodo que Su Señoria Reverendísima celebró a quatorze dias del mes de octubre del año 1572, 2. ed. Madrid 1805. 
o dexaren pedir limosna para ella (...); ni usen las Constituciones o estatutos que después de erigidas por nos, hicieren de nuevo sin la dicha aprovación, so la misma pena, y la cofradía y estatutos sin esta aprobación sean en sí ningunos».

Del mismo modo se prohíben los cultos internos, independientemente de la aprobación de las reglas, sin licencia expresa del prelado: "Mandamos por muchas razones que a ello nos mueve, que de aqui adelante ninguna iglesia parroquial, ni monasterio deste nuestro Arzobispado, haga procesiones por defuera de la iglesia en fiesta alguna, sin nuestra expresa licencia".

El juramento por el que se obligaba a los cofrades al ingresar en la corporación, cuestión que ya venía preocupando desde mucho antes, pues podía darse el caso que aquellos en virtud del mismo se sintieran antes miembros de su hermandad que de la comunidad diocesana, también fue objeto de la atención del sínodo. Así, en el título VI De iure iurando, se ordena que

"en las cofradias que hubiere estatuto que el que entrare haya de jurar los estatutos y constituciones dellas, no se guarde, ni los cofrades juren esto, ni otra cosa alguna. Y por esta nuestra Constitución relaxamos todos los iuramentos que hasta aquí se hubiesen hecho, y damos facultad a todos los curas, que desto lo puedan absolver, y en lugar deste juramento podrán poner otras penas».

De esta forma, como se contempla en una de las pocas reglas que se conservan, las de las Angustias y Transfixión de Nuestra Señora, el juramento fue sustituido por la fórmula menos vinculante del prometo ${ }^{7}$.

El título De celebratione missarum et divinorum officciorum trataba, entre otros temas, de los cultos y procesiones nocturnas, que daban lugar a algunas desviaciones litúrgicas e, incluso, escándalos. Por consiguiente se decretó que

«la noche de Navidad, ni otro tiempo del año, no se digan ni se hagan cosas deshonestas, ni profanas en las iglesias, cantadas ni representa-

\footnotetext{
“Otrosí ordenamos y tenemos por bien que por cuanto en el uso que se solía tener de rescebir juramento al hermano que entrava en esta cofradia, y en ello corría mucho peligro a las conciencias, porque muchos no podian dexar de perjurarse, que de oy más se resciban y entren en la manera siguiente, sin juramento". Reglas y Hordenanças de la cotradia de las Angustias y Transfixion de Ntra. Sra. Granada 1545, Archivo de la Hermandad. Vid. LópEz MuÑoz, M. L., "Las Ordenanzas de la Hermandad de Nuestra Señora de las Angustias de Granada en el siglo Xvin, Chronica Nova, 17 (1989).
} 
das (...), ni se hagan representaciones algunas, ni se canten coplas o canciones sin nuestra especial licencia (...); y assimismo mandamos que no se prediquen sermones de noche el jueves o viernes santo, ni en otro qualquier tiempo del año, sino antes que anochezca, o despues de amanecido, ni tampoco se hagan procesiones de noche, ni vigilias en iglesias $y$ ermitas, por muchos inconvenientes que por experiencia se han visto, salvo las noches del Nascimiento de Nuestro Señor Jesucristo y el Jueves de la Cena, y la mañana de Resurrección, por ser fiestas tan principales. $Y$ encargamos a nuestros visitadores, vicarios, curas y beneficiados, que en estas noches visiten las iglesias, andando con un hacha encendida por ellas, para que no se hagan deshonestidades, o haya desorden algunos, y si necesario fuese hagan poner hachas por el cuerpo de la iglesia para el mismo efecton.

Del carácter festivo y hasta licencioso en que frecuentemente incurrían las procesiones, como se aprecia claramente en las declaraciones que se tomaron con motivo del proceso de reducción de 1597, se ocupa el título $\mathrm{XVIII}$ De reliquiis et veneratione sanctorum et templorum.

«Se prohibe llevar comidas a las iglesias y vender confites, turrones, y otras golosinas en las puertas de las iglesias, ni anden por dentro o por los cementerios aguadores. $Y$ por la desvergüenza de muchos malos cristianos ha llegado a profanar las iglesias, procesiones, jubileos y otras estaciones y perdones, hablando en ellos a mugeres, y haciéndoles señas, y otras deshonestidades, incitando con sus malas costumbres y tratos a diversas ofensas de Nuestro Señor (...), manda que se separen hombres y mugeres, y en las procesiones no estén parados ni les hagan señas o digan otras deshonestidades y que en la calle vigile el brazo seglar».

Finalmente se regula la presentación de las imágenes tanto en el interior de los templos como en las procesiones, lo que demuestra que ya en fechas muy tempranas y anteriores a la exuberancia barroca, las imágenes, especialmente de la Virgen, solían adornarse y vestirse.

“Nuestros juezes tengan particular cuidado que en el uso de las imágenes y reliquias de santos y nuevos milagros se guarde y cumpla lo ordenado por el Santo Concilio de Trento, quitando qualquier abuso que en esto haya, especialmente en el ornato de las imágenes, que no se consientan vestidas en iglesias, procesiones, ni otro lugar, y en lo demás allí contenido".

En general don Pedro Guerrero no innovó nada, sólo reiteró unas normas que sus antecesores ya habían dado, reflejando la problemática originada por el desarrollo de las hermandades penitenciales. Por ello hay reglas anteriores al sínodo en que ya se recogen algunas de estas disposiciones como, por ejemplo, la supresión del juramento o las salidas 
nocturnas ${ }^{8}$. De todas formas se le hizo poco caso y al final de su pontificado persistían los mismos problemas cuanto no más graves.

\section{LAS MEDIDAS DE DON JUAN MÉNDEZ DE SALVATIERRA}

El nuevo arzobispo, Juan Méndez de Salvatierra, ante el poco éxito obtenido por su antecesor, volvió a ocuparse del tema en unos "capítulos de reformación" que dio en $1582^{\circ}$. Por lo que atañe a las cofradías de penitencia, se preocupa por la presentación de las imágenes y el excesivo número de éstas en los desfiles procesionales.

Con respecto al primer punto, don Juan Méndez va a ratificar las disposiciones tridentinas, las constituciones sinodales de 1572 y el decreto que don Pedro Guerrero dio al año siguiente recomendando que las imágenes no se hicieran para vestir, sino de talla dorada y policromada ${ }^{10}$. Por consiguiente, en el capítulo VII ordenaba que se retirasen del culto ya que les ponen «sayas guarnecidas, alçacuellos enriçados, lechuguillas (...), y lo peor es que las suelen afeitar y poner color, cosa indecente aun para las mugeres profanas, para lo qual se piden prestadas ropas, las quales después se ven puestas en mujeres particulares, de lo qual ay escándalo».

Por otro lado, en el capítulo VIII, se intenta frenar los excesos barrocos en que caian, cada vez con mayor frecuencia, los desfiles penitenciales con profusión de imágenes y escenas del Antiguo y Nuevo Testamento que nada tenían que ver con sus advocaciones ni con sus fines, exhortando a los cofrades a no sacar pasos ni «representaciones con ymágenes de las historias sagradas", sino sólo las titulares.

Poco después, en la cuaresma de 1587, el arzobispo volverá a ocuparse del tema, ahora de manera exclusiva, al promulgar un mandamiento sobre «lo que an de guardar las cofradías de Semana Santa» ${ }^{11}$, después

a La situación, por lo demás, no era privativa de Granada. Por ello el tema no sólo preocupaba a la jerarquía eclesiástica sino a la Corona. Asi, Carlos $V$ intentó controlar las cofradias como se observa en una real pragmática de 1552 (Nueva Recopilación, leyes 3 y 4, tit. 14, lib. 8 y Novísima Recopilación, ley 13, tit. 12, lib. 12) cprohibiendo absolutamente el que se erigiesen cofradías por causas pías y espirituales, sin preceder la licencia del principal, y con autoridad del prelado, declarando nulas $e$ insubsistentes las que no tuviesen estas aprovaciones, baxo graves penas a los que se juntasen sin ellas». Escolano de Araieta, P., Práctica del Consejo Real. Madrid 1796, l, pág. 393.

9 A(rchivo) C(atedral de) $\mathrm{G}$ (ranada), lib. 20, págs. 916-920.

10 López Muñoz, M.L., Contrarreforma y cofradias en Granada. Aproximación a la historia de las cotradias y hermandades de la ciudad de Granada durante los siglos XVII y XVII. Granada 1992, Tesis doctoral inédita, pág. 725.

"ACGR, leg. 84, pza. 4. 
de haberlo tratado no sólo con «personas graves de sciencia y consciencia», sino también con los responsables de las propias cofradías.

En primer lugar se ocupa de la disciplina pública que es el rasgo distintivo de las cofradías de penitencia. Méndez de Salvatierra era consciente del valor que encerraba este método de ascesis, obra "muy sancta y de mucho mérito para las ánimas de los que lo hazen y exemplo de los que lo ven", pero, al mismo tiempo, no podía dejar de reconocer los excesos y abusos en que incurrían muchos disciplinantes. Era ocasión de pecados y ofensas aprovechando la "obscuridad de aquellas noche - jueves santo - y el tumulto de la gente"; de faltar a los oficios del día pues “dexan de acompañar al Sanctísimo Sacramento en los monumentos (...) distrayéndose en la devoción»; $y$, en fin, de incumplir el ayuno upor aver pasado tanto tiempo después de la comida de mediodía».

Por consiguiente, ordenaba a las cofradías que salían el jueves santo, Vera Cruz, Angustias y Ánimas, que adelantaran su salida a las primeras horas de la tarde para que estuvieran de regreso antes del anochecer pues «de aquí en adelante ninguna procesión de disciplinantes, ni otra ninguna, salga de noche, ni en otra ora en que pueda bolver de noche». $Y$ si hubiese disciplinantes que, a pesar de lo dispuesto y acordado con los oficiales de sus cofradías, organizaran cuadrillas autónomas para «salir por sí aquella noche y (...) defraudar el sancto fin e propósito que se a tenido en esta reformación (...), se procederá contra ellos con todo rigor». También prohíbe las disciplinas en la mañana del domingo de Resurrección, costumbre cada vez más extendida en Granada, pues era una práctica contraria a la liturgia en un "día de tanto regozijo y en que tanto se deven alegrar las almas christianas".

El excesivo número de pasos e insignias al que hacía referencia en sus «capítulos de reformación», vuelve a ser objeto de su atención al ordenar que "nynguna cofradia ni procesión que se hiziese saque más de cinco ymágenes e insignias fuera del estandarte, excepto la cofradía de la Pasión (...) que a de sacar seys".

En las primitivas procesiones de penitencia el uso de la cera tenía sólo un carácter funcional, alumbrar el camino a los hermanos de sangre y facilitar la labor de sus auxiliares, conserveros y restañadores, pero poco a poco se convirtieron en hermanos de luz, aumentando considerablemente su número y convirtiéndose el consumo de cera, por ende, en uno de los capítulos más onerosos de las finanzas de la cofradía. Teniendo en cuenta que a partir del mandamiento ya no habría procesiones nocturnas, el arzobispo dispuso que sólo "se puedan llevar doze hachas a costa de los cofrades y no más» en torno a las imágenes de "Nuestro Señor Jesuchristo o de su preciosísima Madre" y seis con las de "los 
sanctos de las advocaciones". Asimismo prohibió los hermanos de luz, «aunque sea por devoción», pues, “es de día (...) y no ay nescesidad de lunbre».

Para garantizar el cumplimiento de estas disposiciones, disposiciones que previamente habían sido negociadas con las respectivas juntas de gobierno, ordenaba, por último, que en las procesiones «ninguna persona se entremeta a regir ni governar las dichas cofradías sino fuere por orden y mandado de los dichos hermanos mayores y priostes dellas».

Todo esto estaba dirigido a evitar los «muchos inconvinientes» que causaban las procesiones y perjudicaban los oficios del día. Por tanto, sin procesiones nocturnas y sin gasto de cera, los fieles podrían acudir a sus parroquias la noche del jueves santo «a acompañar su sanctísimo cuerpo Sepultado en el monumento con mucha devoción y recogimiento, sosiego y quietud, dando buen exemplo y sin escándalo" y contribuir "con la cera para alumbrar los monumentos, pues antes lo solían gastar en alumbrar los disciplinantes".

Como más adelante se lamentaría otro prelado ${ }^{12}$, el Mandato, leído en la Catedral el día 15 de marzo, provocó de inmediato la oposición no sólo de los cofrades y fieles sino del propio cabildo. Cinco días después los capitulares presentaron un escrito protestando por no haber sido consultados previamente en asunto de tanta gravedad. Además salían en defensa de las cofradías pues el ordinario, según ellos, no tenía facultad para alterar "el estado que oi día las dichas cofradías tienen ni el fin de su instituto (...), ni es parte para desconcertar ni mudar la forma e orden de la salida y buelta a sus casas, tiempo e lugar, cera y acompañamiento que se contiene en las dichas bulas e la dicha costumbre general tiene declarado, e el derecho, en quanto a esto, le tiene atadas las manos» ${ }^{13}$.

\footnotetext{
12 En una Relación preparatoria de la visita ad limina que realizaría en 1597, don Pedro de Castro se lamenta del poco eco que hallan sus recomendaciones pues "ni podemos remediar nada los prelados, los que avian de aiudarnos, qualquier suerte que sea de gente, nos ponen impedimento; todo está opuesto y en contradicion y embaraços; en llegando a papel y tinta no se hace nada; luego entra la apellacion y la fuerça y está en tal estado que quiza seria peor que hablasemos. Emos de procurar el remedio con artificio, estan las cosas para nos yr a los yermos y andar siempre yorando, como Hieremias". Relación del Estado y Govierno de la Yglesia Metropolitana del Arzobispado de Granada, fol. 38. Vid. Marín López, R., "Un memorial de 1594 del arzobispo de Granada don Pedro de Castro sobre su Iglesia con motivo de la visita ad limina, en Revista del Centro de Estudios Históricos de Granada y su Reino, 7 (1993); en prensa.

13 ACGR, leg. 84, pza. 4.
} 


\section{LAS MEDIDAS REDUCTORAS DE 1597}

Aunque don Pedro Guerrero y don Juan Méndez pusieron en práctica las primeras disposiciones conciliares, será don Pedro de Castro y Quiñones, un prelado ascético y severo y celoso de sus prerrogativas jerárquicas y de su independencia en lo espiritual frente al poder civil, quien mejor represente en Granada el nuevo espíritu y concepto religiosos elaborado en Trento.

Por ello no es de extrañar que ante el fracaso de las medidas correctoras de sus antecesores el arzobispo, que ya había demostrado su energía en otros asuntos de la diócesis, ordenara dias antes del comienzo de la Semana Santa de 1597 la apertura de un expediente sancionador contra todas las hermandades de penitencia ${ }^{14}$.

La medida no era novedosa ni siquiera privativa de Granada pues por esas mismas fechas se adoptaron disposiciones semejantes en otras diócesis. Pero lo que sí presenta cierta originalidad es la forma como se desarrolló el proceso y la severidad de las medidas adoptadas, circunstancia en la que influyó en gran manera el estado un tanto inquieto de la ciudad por la cuestión morisca y el carácter del prelado ${ }^{15}$. Por ello no es de extrañar la fecha elegida, que apenas permitiría reaccionar a las cofradías, y la rapidez con que se celebró el proceso.

Antes de tomar decisión tan drástica el arzobispo ya había señalado los males que padecían las cofradías en una Relación del Estado y Govierno de la Yglesia Metropolitana del Arzobispado de Granada preparada en 1594 con motivo de la visita ad limina que efectuaría dos años más tarde $^{16}$.

Aunque en esa relación las referencias a las hermandades apenas si ocupan un folio, son suficientes para conocer la situación de esas cor-

14 Ortega Sagrista, R., "Esplendor de la Semana Santa granadina y de sus cofradias en el siglo XVI". Jaén 1961, trabajo inédito. Vid. Szmolka Clares, J., "La historia de la Semana Santa...", op. cit., págs. 57-61.

15 «Pequeño de cuerpo fue el Arçobispo, pero de gran cabeça, cultivada con estudios y experiencia de muchos negocios que había manoseado en dos Chancillerías; noticias con que anteveia los sucessos del gobierno y prudente prevenía los aciertos. Fue de condición cerrado y secreto, sus acciones las gobernaba con consejo, pero no las divulgaba hasta su efecto, aunque pareciessen mal al pueblo, asseguraba con silencio el sucesso. Penetrava con agudeza la infención de los que tratavan con él, y respondia a su pensamiento a vezes. Fue amigo de verdad, y enemigo de quien lo era della. No se dexava llevar del primer informe. Tenía gran espera en los negocios, y gran destreza en guiailos con prudencia". Bermúdez de PedRAZA, F., Op. cit., fol. 265 .

is Vid Marín López, R., Op. cit., en prensa. 
poraciones por el acertado, completo y profundo análisis que hace don Pedro de Castro.

La causa principal, como más adelante se verá en el proceso que condujo a la reducción, era el excesivo número de cofradías. Diez hermandades, en una ciudad de las características de Granada, eran, efectivamente, una cantidad elevada. Ello hacía que tuvieran muy pocos hermanos $y$, por consiguiente, muy pocos ingresos. Ante la insuficiencia de las cuotas se recurría a las demandas públicas y, como también éstas eran exiguas, al esfuerzo personal de sus mayordomos y oficiales que «porque no los tengan en menos (...) suelen quedar empeñados y alcançados y con nescesidad». Por esa escasez de hermanos tampoco se podía cubrir con dignidad las filas de disciplinantes recurriéndose a contratar mercenarios que, además, solían comprometerse con varias hermandades al mismo tiempo y quebrantando, ante su excesivo trabajo, el precepto del ayuno y abstinencia. Por último, aunque "por que no se encuentren en las calles les señala el prelado horas a que an de salir", siempre terminaban tropezando una con otra originando altercados y enfrentamientos.

Por todo ello, concluía el arzobispo «si se reduxesen a tres o quatro cesarian estos inconvinientes, serían más abultadas, con más número de cofrades y aprovecharles ya más la limosna, serian mejor regidas y no se encontrarian".

Tras su visita a Roma, donde había expuesto sus intenciones ${ }^{17}$, dio el paso decisivo emprendiendo un proceso que culminaría en la suspensión de siete de las diez corporaciones de penitencia que existian en la ciudad. Entre el 20 y 23 de marzo se tomaron declaración a los hermanos mayores y otros oficiales de las cofradías y este último día, concluido el desfile de los testigos, el fiscal expuso sus conclusiones. En ellas el licenciado Mateo de Basagutia venía a confirmar lo denunciado tres años antes en la $R e$ lación de don Pedro de Castro, considerando que existían demasiadas cofradias por to que no se cumplia el horario y orden de precedencia que de acuerdo con su antigüedad les habian sido dadas; que por esa misma razón tenían pocos hermanos y la mayoría de ellos debían dedicarse a pedir limosnas, limosnas que se empleaban en cosas superfluas pues

\footnotetext{
"Lites inter eos mascuntur ab multitudinem Confraternitatum, et super preeminentia antiquitatis, et licet Prelatus curat super his providere horas asignando quibus incidere debeat, hoc tamen non adimplet, sed litigiose et indecenter alia aliam precedit. Ita ut non possint eos mitigare judices ecclesiastici nec seculares, si ad tres vel ad quatuor reducerentur omnia haec inconvenienti cesarent et de magis inservirent». Visita de 1596, A(rchivo) S(egreto) V(aticano), S. Congr. Concilii, Relationes, leg. $370 \mathrm{~A}$.
} 
“las gastan como quieren los oficiales, excediendo de lo que mandan sus reglas. Sus procesiones se encuentran en la calle con grave escándalo; pagan cuadrillas de disciplinantes para ir más acompañadas, y les dan mucho y bien de cenar y colaciones, con lo que quebrantan el ayuno, y con tanta disciplina se desangran y llegan a morir en ello".

En consecuencia, concluía, aconsejaba al provisor que procediera a una reducción de las mismas.

De inmediato el provisor, Agustín Antolínez de Burgos, notificó lo acordado a los distintos hermanos mayores y mayordomos que volvieron - como días antes en las diligencias previas - a demostrar su poca solidaridad. En este sentido el prioste de la hermandad de Santa Elena y Jesús Nazareno declaró que sólo debía quedar la suya pues sus constituciones prohibian los disciplinantes y las demandas públicas, mientras que el de la Oración en el Huerto, consciente de que su cofradía era una de las que se encontraban en entredicho, argumentó que en ella «no se usa lo que toca a colaciones ni cenas; no se encuentra con otra porque guarda la orden que le tienen dada y la gente que en ella va son escribanos y tiene más de seiscientos hermanos, y le parece muy bien que las cofradías se reduzcan a la mayor, y por tanto a esta suya, por ser muy antigua". Las restantes, con excepción de la hermandad trinitaria de la Pasión que no compareció, alabaron la idea y quedaron a expensas del provisor por convenir "al mejor servicio de Nuestro Señor y del Rey».

En fin, el 20 de marzo, miércoles de la semana de Pasión, el fiscal emitió el siguiente auto:

"Habiendo visto los autos e informaciones de este proceso y lo pedido por el fiscal del Arzobispo contra las cofradías que hacen procesión de disciplinantes y penitentes de cruces en esta ciudad, y las confesiones de los priostes, mayordomos y otros oficiales y hermanos de ellas, dijo: Que mandaba y mandó que de aquí adelante las cofradías de la Vera Cruz, las Angustias y la Soledad, guarden en sus procesiones la orden que les está dada en la hora de salida, cera e insignias. Y que la cofradía de las Angustias salga de aquí adelante el viernes santo por la mañana a las seis en punto. $Y$ que en las dichas cofradías no se dé colación, ni vino so pena de excomunión. Y mandó que ninguna de las demás cofradías de aquí en adelante, no hagan ni saquen procesiones con disciplinantes y penitentes de cruces, so pena de excomunión, y no saquen cuadrillas a disciplinarse. Y si para la ejecución de lo susodicho fuera necesario invocar el auxilio del brazo seglar, desde luego lo invocaría y lo invocón.

Conocido el veredicto y tras unos momentos de desconcierto, las cofradías afectadas se aprestaron a neutralizar la orden. El hermano mayor de la Humildad y Paciencia decidió apelar a la jurisdicción civil, pues 
«estando asentado, proveido e determinado en todos los reinos de Su Magestad y en los extraños donde ha habido y hay católicos e fieles a nuestra santa fe, de en remembranza e fiel recordación e aumento de gracia por la gran misericordia que Dios Nuestro Señor obró en el género humano, en lo haber redimido, en el tiempo de la Semana Santa hacer procesiones e prerrogativas e plegarias con disciplina e efusión de sangre, los dichos hermanos habían instituido e formado la dicha cofradía con orden e aprobación del perlado, estando en uso de sus derechos muchos años a esta parte en todos los miércoles de Semana Santa».

En similares términos se pronunciaron los cofrades del Santo Crucifijo y Ánimas del Purgatorio alegando que

"en Sevilla y Madrid hay muchas cofradias y no las han reducido. $Y$ si han intentado reducirlas, vistos los grandes inconvenientes han desistido. Y de hacerlo debió de ser con más tiempo y no aguardar a la Semana Santa invocando la fuerza y el auxilio de Vuestra Alteza. $Y$ el provisor no ha querido devolver a mis partes su bula ni las reglas con ánimo de que no pudiesen acudir ante Vuestra Alteza antes de las vacaciones a que. rellarse. Dicho auto es en gran manera perjuicio de nuestra cristiana religión, pues por muy leves causas y lesivos inconvenientes, que fácilmente por otras vías se pudieran remediar, quiere quitar tantas obras buenas como se hacen en estas procesiones de disciplina así de culto divino y honra de las santas imágenes y memoria y representación de la Sagrada Pasión de Nuestro Redentor, en los pasos, insignias y en aquella efusión de sangre, como en la penitencia y obras penales con que los fieles que allí se azotan satisfacen por sus culpas. $Y$ no es justo presumir que en tanta muchedumbre no haya algunos y muchos que lo hagan por amor a Dios y con las debidas circunstancias, como en la devoción del pueblo cristiano que con aquel espectáculo y viva representación de estos tiempos abominan y detestan. $Y$ si en la ejecución hay algunos defectos, con penas y censuras se pueden remediar y no quitar las buenas obras de raiz".

Más críticos fueron otros hermanos mayores al denunciar los métodos poco ortodoxos usados por el arzobispo y sus colaboradores. Así la hermandad de la Oración en el Huerto denunció que ahicieron que dijese que lo consentía sin poderlo hacer, ni dejar defenderse»; y los hermanos de la Cruz de Santa Elena y Jesús Nazareno que, por no ser de sangre, creían que la reducción no les afectarian amenazaron con llegar hasta Roma al tiempo que acusaban al provisor pues "con cautela y dolosamente pidió las bulas y constituciones de nuestra cofradía, que están aprobadas por él, y esperando con el mismo dolo que no hubiese Audiencia Real para defendernos".

Finalmente todas recurrieron a la Chancillería y al corregidor que, en contra de lo usual en la época, actuaron con rapidez para acallar las primeras muestras de inquietud y descontento que ya habian aparecido 
en la ciudad. Al día siguiente, sábado de Pasión, la Audiencia ordenó a los notarios eclesiásticos que se personaran con los autos originales para hacer relación de ellos. Una vez examinado por los oidores el expediente eclesiástico, se dictó un auto que anulaba el del arzobispo, facultando a las hermandades de Santa Elena y Ánimas para salir en procesión y, por tanto, a las restantes suspendidas.

Sin embargo, don Pedro de Castro hizo caso omiso al auto de la Chancillería. Agustín Antolínez, el provisor se inhibió arguyendo que la causa la tenía reservada el prelado y éste impidió la entrada en su cámara al notario de la Audiencia por lo que no se dio por enterado. Todavía más, el jueves santo ordenó que se pregonara en todas las iglesias que serían excomulgados todos los que participaran en las procesiones de las cofradías suspendidas y los que las ordenasen y rigieren. Para evitar males mayores los responsables de las siete hermandades acordaron ante notario no salir ese año y continuar después la apelación.

Semanas después la hermandad de Santa Elena y Jesús Nazareno inició los trámites para proseguir la apelación y 10 mismo hicieron los cofrades del Santo Crucifijo y Ánimas. Sólo se conocen noticias del pleito de estos últimos; no se sabe si porque fueron los únicos que perseveraron hasta el final o porque se perdiera la documentación de los demás. A petición de los mismos se abrió información pública en la que participaron dieciséis testigos cuyas declaraciones constituyen una preciosa fuente para conocer la vida y los problemas de estas primitivas corporaciones penitenciales, y posteriormente obtuvieron un breve del nuncio que les permitía recurrir a los restantes jueces de la provincia eclesiástica.

El pleito en grado de apelación no resolvió nada. Los procuradores diocesanos argumentaron defectos de forma y, aunque se intentó corregirlo, al final el 16 de marzo de 1598, días antes del inicio de una nueva Semana Mayor, el licenciado Antonio Sarmiento de Mendoza, arcediano de Úbeda y dignidad de la catedral de Jaén, determinó que uel dicho pleito no venía por la vía que había de venir, y así mandaba e mandó que la parte de la cofradía haga sus diligencias como vieran les conviene en cumplimiento de los mandamientos por su Merced discernidos, y habiendo hecho lo que son obligados y viniendo dicho pleito por la forma que ha de venir, está presto de proveer justicia".

Días más tarde la hermandad decidió recurrir ante la Santa Sede a lo que el juez episcopal respondió que lo oía y mandaba que se notificara y diera traslado a la parte contraria. De esta apelación a Roma nada se sabe, lo más probable es que terminase con una condena definitiva para la hermandad dominica, circunstancia que parece confirmar el hecho de que no volviera a procesionar nunca más, como hicieron las demás co- 
fradías en la centuria siguiente, lo que hace preguntarse a Francisco Henríquez de Jorquera "oy no sé porqué no sale" ${ }^{18}$.

\section{RECUPERACIÓN Y CONSOLIDACIÓN DE LAS HERMANDADES DE PENITENCIA GRANADINAS}

Fray Pedro González de Mendoza por su origen familiar y su formación religiosa era muy distinto a don Pedro de Castro. Emparentado con la alta aristocracia castellana -en él confluían las grandes casas del Infantado, Alba y Medinaceli-e hijo espiritual de San Francisco en cuya orden desempeñó diversos cargos de responsabilidad, representa la vertiente triunfal y expansiva de Trento y de la Reforma Católica. Sin embargo no se puede entender su obra sin tener siempre presente la labor de su antecesor. Don Pedro de Castro desarrolló una importante actividad reformadora y disciplinaria en la sede de San Cecilio por lo que fray Pedro quedó con las manos libres para actuar en esta segunda parcela más vistosa y menos ingrata. Francisco Bermúdez de Pedraza lo expresa claramente en su semblanza biográfica: "Visitó su Iglesia, y no halló que reformar en lo formal della, pero reparó lo material del templo, y en la hermosura del edificio, y culpó lo poco que en tantos años avía crecido su fábrica". Por tanto el nuevo prelado "empleará todas sus fuerças" en engrandecer la diócesis tanto en sus edificios emblemáticos - catedral y palacio arzobispal- como en sus miembros que, pese a las providencias de sus antecesores, continuaban padeciendo la crónica penuria impuesta por fray Hernando de Talavera. Por ello y dado que era "aficionado a labrar", refiere Bermúdez de Pedraza, "empleó todas sus fuerças en continuarla, y adelantó buena parte de la obra, y estuviera acabada si Dios no le uviera trasladado a otras Iglesias (...) y edificó un palacio Arçobispal (...), obra digna de tan gran Príncipe». Por otra parte, «desseó ver luzidos a sus Prebendados, ricos de honor y pobres de prebendas, y aumentolas con algunas distribuciones, asignadas al servicio del Culto divino" ${ }^{19}$. Como esos fines exigían cuantiosos gastos hubo de buscar nuevas fuentes de ingresos o engrosar los ya existentes. Aumentó, por consiguiente, los derechos de algunos servicios prestados por el cabildo y, por otro lado, impuso a las cofradías una contribución de cien ducados para el dorado de la capilla mayor de la catedral como medida previa a la autorización para realizar sus estaciones.

18 Henriquez de Jorquera, F., Anales de Granada. Granada 1987 (reed), pág. 232.

19 Bermúdez de Pedraza, F., Ob. cit., fol. 274. 
Esta razón material, ciertamente, influirá en el levantamiento de la suspensión de las cofradias, mas no hay que olvidar el valor catequético y ejemplarizador que los padres conciliares vieron en ellas. De esta manera, el prelado paulatina y prudentemente irá autorizando la salida de las hermandades suspendidas. En abril de 1611, primer año de su pontificado, autorizó la salida de la cofradía de la Humildad y Paciencia de Jesucristo; al año siguiente a las de Jesús Nazareno y Oración en el Huerto, mientras que en 1613 y 1614 levantó el interdicto a las hermandades de la Sangre de Jesucristo y la Sagrada Pasión. Sólo quedarían sin salir las cofradías de la Expiración de Cristo y de las Ánimas del Purgatorio.

Recuperadas la mayoría de las corporaciones penitenciales, se puede afirmar sin reparos que en el primer tercio del Quinientos la Semana Mayor granadina vivirá una de sus etapas de mayor brillantez.

Las tres cofradías permitidas por el arzobispo Castro, sin problemas de itinerario ni competencia en las demandas aumentaron sus nóminas de hermanos $y$, en general, alcanzaron su consolidación. Mientras tanto las restantes hermandades, dedicadas únicamente al culto interno, llevaron una vida lánguida y dificultosa que las dejaron al borde de la extinción. Sin embargo, se recuperaron con rapidez e incluso llegaron a superar el esplendor logrado antes de 1597. Así la hermandad de la Humildad y Paciencia realizó en la tarde del miércoles santo de 1611 una procesión ejemplar por lo devota, igual que al año siguiente las cofradías de Jesús Nazareno y la Oración en el Huerto, pues, «la buena solicitud de los hermanos mayores y mayordomos lo travaxaron mucho con sus personas y haciendas" ${ }^{20}$. En esta última destacó la cantidad de gente noble que le acompañó. Acompañamiento que también llevaron en 1613 en su reaparición la hermandad mercedaria de la Sangre de Cristo y un año después la de la Sagrada Pasión.

La labor positiva de fray Pedro González de Mendoza concluyó con la fundación de una nueva corporación en la cuaresma de 1616. La nueva hermandad, Santo Entierro de Jesucristo y Nuestra Señora de las Tres Necesidades, presentaba algunos rasgos orientales al parecer, según Francisco Henríquez de Jorquera, impuestos por el ordinario. Se fundó en una iglesia parroquial, hecho desusado en estos años, lo que confirma la línea iniciada por don Pedro de Castro al convertir la iglesia de las Angustias en parroquia para evitar el asentamiento de una orden religiosa; $y$, además, se ordenó a sus hermanos que salieran sin «ninguna gente

20 Henriquez de Jorquera, F., Op. cit., pág. 580. 
de açote». Esta última circunstancia, cuyos motivos son obvios, evitar la antigua lucha por la captación de disciplinantes, permitirá que Granada cuente desde esta fecha con el tercer tipo de cofradía barroca de la que carecía por entonces, la simple procesión intimamente ligada a los oficios del día, en la que se combinaba la dramatización del misterio con la estación penitencial ${ }^{21}$.

El auge cofradiero que se registró durante el pontificado de fray Pedro González de Mendoza no acabó con los viejos hábitos, muy al contrario los agravó. Continuaron los mismos problemas, los piques entre cofradias, los gastos excesivos con menoscabo de los fines primordiales como eran la caridad y las exequias de los hermanos, las demandas constantes que agobiaban al ciudadano en cualquier tiempo, no sólo en cuaresma... Precisamente esta última cuestión dio origen a una nueva suspensión. En la cuaresma de 1631 el doctor Juan Palacios, provisor y vicario general, a ruegos del cabildo catedralicio prohibió a todas las cofradías que no fueran sacramentales pedir limosna bajo graves penas uporque avía hermandad que echava tres y quatro demandas cada día (...) que no les bastavan a la gente" ${ }^{22}$. La medida no debió surtir mucho efecto pues unos días más tarde, domingo de Ramos, el provisor tuvo que emitir un nuevo auto en nombre del arzobispo y presidente del Consejo de Castilla, don Miguel Santos de San Pedro, por el que suspendían todas las cofradías menos las tres más antiguas. Aunque se desconocen en detalle los pormenores del proceso, todo indica que se hizo exactamente igual que en 1597, manteniéndose en secreto hasta última hora para impedir que las cofradías apelasen. Así cuando éstas conocieron al auto no pudieron hacer otra cosa que protestar y suplicar un aplazamiento porque ya tenían hecho todos los preparativos y gastos. Todo fue inútil pues ante la amenaza de excomunión y multa de doscientos ducados los hermanos mayores no tuvieron más remedio que dejar las imágenes en sus templos.

En esta ocasión la suspensión fue muy breve. Dos años más tarde, estando la sede vacante por fallecimiento del arzobispo, el provisor don Alonso García de Villamayor autorizó la salida de las cofradías de Jesús Nazareno y de las Tres Necesidades, procesiones que al igual que las otras hermandades, resultaron «muy lucidas y copiosas" ${ }^{23}$. Al año siguien-

21 Szmolka Clares, J., “Historia de la Semana Santa...”, op. cit., pág. 66. Vid. también "Un pleito entre las primitivas hermandades granadinas de las Tres Necesidades y Soledad por la organización del Santo Entierro", en En torno al Santo Sepulcro, "Actas del Tercer Encuentro para el estudio cofradiero". Zamora 1993 (en prensa)

22 Henríquez de Jorquera; F., Op. cit., pág. 720.

${ }^{23}$ Ibidem, pág. 731 
te, autorizadas por el nuevo prelado don Fernando de Valdés y Llano, reaparecieron las de la Sagrada Pasión y Sangre de Jesucristo también "con mucha hostentación y cera y lo demás de lucimiento» ${ }^{24}$.

Como las demandas constituían el único medio de financiación importante que tenían las cofradías, pronto se olvidaron las prohibiciones y censuras y en 1637 el arzobispo se vio obligado a renovar el auto de 1631 que las prohibía tajantemente. Parece que de momento y en previsión de males mayores, las cofradías obedecieron pero algunas, privadas de su principal medio de subsistencia se vieron en graves aprietos e, incluso, las Tres Necesidades, pese a su importancia, no pudo salir al año siguiente "por falta de dineros, y estar empeñada y no aver tenido demandas» ${ }^{25}$.

Fue un nubarrón sin importancia pues las Semanas Santas siguientes resultaron igual de brillantes. Así en 1639 la cofradía de la Oración en el Huerto, que reaparecía tras ocho años de suspensión, «salió grandiosisima que ubo mucho que ver" hasta el punto que los hermanos de la Soledad queriendo emularla y superarla hicieron tan grandes gastos que obligó al provisor a suspender su salida el mismo viernes santo porque «los grandes gastos que tenían hechos (...) más pertenescian para fiestas que para tristeças" ${ }^{26}$.

Ni la crisis que por esos años padecía la ciudad ni las amenazas del provisor sirvieron para moderar los impulsos de los cofrades granadinos pues en 1640, año si cabe más crítico que los anteriores, las procesiones resultaron igual de ostentosas. La cofradía de San Antón incluso llegó a superarse y, según Francisco Henríquez de Jorquera que no puede ocultar su admiración, "salió tan opulenta y grandiosa que no se a bisto en esta ciudad; fueron novecientas hachas por número, las quales salieron en esta cofradía con banderolas grandiosas. Fue tanta jente que salio a ver esta cofradía que no se podía rejender por las calles." Las demás no le fueron a la zaga, y las Tres Necesidades, sin duda recuperada de su pasajera crisis, logró lo que su rival carmelita no pudo conseguir el año anterior. Su procesión fue

«tan grandiosa que la abentajó en grandeça con tantas cosas nuebas de la Escritura, cargada con tanto primor y con tantas banderolas como pasos. Salió en ella toda la cavallería y nobleça de Granada delante, con hachas, llevando el estandarte el conde de Santiestevan, llebando las 
borlas del estandarte don Juan Luis Ponce de León y otro gran cavallero, todos los tres de la horden de Santiago; salieron en el paso de Nuestra Señora todos los escribanos del número de Granada con sus hachas. Fue tan larga que duró de pasar por la Santa Yglesia ora y media larga, con darle priesa la cofradía de la Soledad que sale despues" ${ }^{27}$.

De todas formas fue sin duda el canto del cisne de la Semana Santa granadina del Barroco, pues al año siguiente esa última, junto con la Humildad y la Sangre, se quedaron en sus templos, decisión que en 1642 también hubo de tomar la hermandad de San Antón. Para Henríquez de Jorquera la culpa era de los mayordomos y hermanos mayores upor ser de poco ánimo", pero la realidad era otra, la crisis de la Monarquía Hispánica con guerras tanto dentro como fuera de sus dominios estaba dejando exhausto al país, sin hombres ni dinero, y, en el caso concreto de Granada, había de tenerse en cuenta además los gastos excesivos y extraordinarios que a sus cofradías supuso las procesiones $y$ otros actos de desagravio por el libelo anticoncepcionista que apareció en las Casas Consistoriales, precisamente en la madrugada del viernes santo de $1640^{28}$.

Desaparecieron, por ello, la mayoría de las hermandades, pero las que se mantuvieron junto a alguna que se funda en el tránsito de la centuria, perseveraron en la línea barroca avanzando upor el camino del boato y de la esplendidez (...) hacia situaciones festivas, no muy en consonancia con la contemplación e imitación de la Pasión de Cristo»" ${ }^{29}$.

Consecuentemente seguirán produciéndose roces entre unas cofradías celosas de su tradición y una jerarquía eclesiástica que no estaba dispuesta a permitir que se quebrantara la pureza de los ritos. Roces que, como ha señalado Pedro Castón, eran fruto de la indisociabilidad entre religiosidad y cultura en unas manifestaciones con alta participación popular, con innevitables connotaciones lúdicas y con el predominio de «una estética barroca, sensitiva y sensorial» ${ }^{30}$.

27 lbidem, págs. 846-847.

28 Sánchez Herrero, J., uLas cofradías de Semana Santa de Sevilla durante la Modernidad. Siglos XV a XVIm, en Las cofradias de Sevilla en la Modernidad. Sevilla 1988, pág. 35.

29 CASTÓN BOYER, P., "La religiosidad tradicional en Andalucia. Una aproximación sociológica", en La religión en Andalucía. Sevilla 1985, pág. 123. 